\title{
Bile Acids, Nuclear Receptors and Cytochrome P450
}

\author{
J. JUŘICA ${ }^{1,2}$, G. DOVRTĚLOVÁ ${ }^{1}$, K. NOSKOVÁ ${ }^{1}$, O. ZENDULKA ${ }^{1}$ \\ ${ }^{1}$ Department of Pharmacology, Faculty of Medicine, Masaryk University, Brno, ${ }^{2}$ Department of \\ Biochemistry, Faculty of Science, Masaryk University, Brno
}

Received August 13, 2016

Accepted October 13, 2016

\begin{abstract}
Summary
This review summarizes the importance of bile acids (BA) as important regulators of various homeostatic mechanisms with detailed focus on cytochrome P450 (CYP) enzymes. In the first part, synthesis, metabolism and circulation of BA is summarized and $\mathrm{BA}$ are reviewed as physiological ligands of nuclear receptors which regulate transcription of genes involved in their metabolism, transport and excretion. Notably, PXR, FXR and VDR are the most important nuclear receptors through which $B A$ regulate transcription of CYP genes involved in the metabolism of both BA and xenobiotics. Therapeutic use of BA and their derivatives is also briefly reviewed. The physiological role of $B A$ interaction with nuclear receptors is basically to decrease production of toxic non-polar BA and increase their metabolic turnover towards polar BA and thus decrease their toxicity. By this, the activity of some drug-metabolizing CYPs is also influenced what could have clinically relevant consequences in cholestatic diseases or during the treatment with BA or their derivatives.
\end{abstract}

\section{Key words}

Bile acids • FXR • PXR • Cytochrome P450

\section{Corresponding author}

O. Zendulka, Department of Pharmacology, Faculty of Medicine, Masaryk University, Kamenice 5, 62500 Brno, Czech Republic. Fax: +420 549493 971. E-mail: zendulka@med.muni.cz

\section{Introduction}

The essential physiological role of bile and bile acids (BA) in digestion is to neutralize chyme and serve as emulsifiers of fat in small intestine. Thanks to their amphiphilic nature, BA are emulsifiers which enable absorption of lipids and lipid soluble vitamins. The production and secretion of bile is regulated by intestinal paracrine hormones cholecystokinin and secretin and moreover autoregulation via negative feedback exists, too. BA and phospholipids stabilize micellar dispersion of cholesterol in the bile and facilitate cholesterol excretion as well as excretion of hydrophobic metabolites of xenobiotics, toxins and metals. In past decade, it has been postulated that bile acids may also regulate lipid and glucose homeostasis, thermoregulation, and immune response (Claudel et al. 2011). Especially the role of BA in immune response is undoubtedly involved in the therapeutic effects of some BA in cholestatic liver diseases (Roma et al. 2011, Buryova et al. 2013).

The most common human BA (Fig. 1) are cholic acid (CA), chenodeoxycholic acid (CDCA), in much less proportion also glycocholic acid, taurocholic acid (TCA), lithocholic acid (LCA), deoxycholic acid (DCA), and ursodeoxycholic acid (UDCA). BA and oxysterols are natural ligands of several nuclear receptors (NRs), membrane receptors and regulators of metabolism of lipids and glucose (Chiang 2004, Chiang 2009). At least, some of BA regulate above mentioned pathways via their farnesoid $X$ receptor (FXR) agonistic activity. In particular, FXR agonists probably via production of glucagon-like peptides 1 and 2 increase insulin sensitivity, glucose uptake, and adipogenesis in extrahepatic tissues. Meanwhile, they increase fatty acid oxidation, decrease triglyceride, fatty acid, and cholesterol synthesis in the liver and increase insulin production in beta cells (Camilleri and Gores 2015, Adorini et al. 2012). BA as FXR agonists also decrease 
activity of phosphoenolpyruvate carboxykinase and glucose 6-phosphatase and thus, together with all above mentioned effects increase glucose tolerance and insulin sensitivity (Chiang 2013). BA also promote gut motility through TGR5 activation (Camilleri and Gores 2015) which is in agreement with reported adverse effects of therapeutically used BA (American Society of Health System Pharmacists 2016a, American Society of Health System Pharmacists 2016b). Primary BA are deconjugated and dehydroxylated by microflora, and these BA metabolites exert antimicrobial properties (Begley et al. 2005). Another physiological consequence of BA binding on FXR is increased synthesis of fibroblast growth factor-19 (FGF-19), which may reduce glycolysis and lipogenesis, improved insulin sensitivity, and reduce bile acid synthesis (Camilleri and Gores 2015).
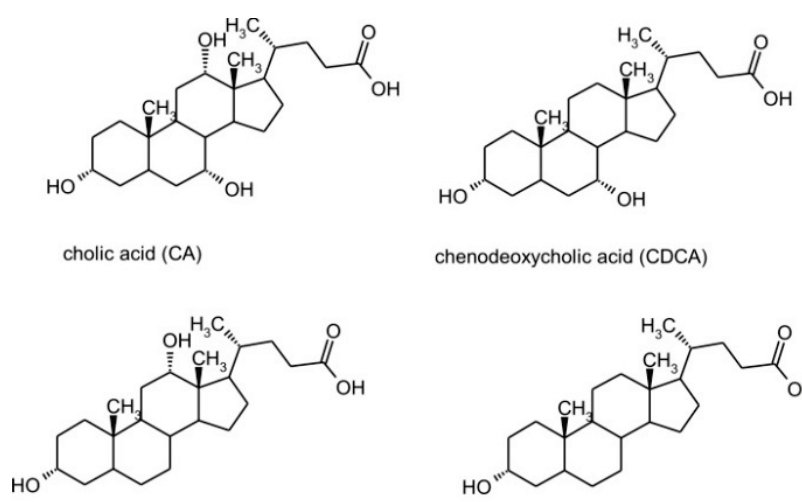

chenodeoxycholic acid (CDCA)

deoxycholic acid (DCA)

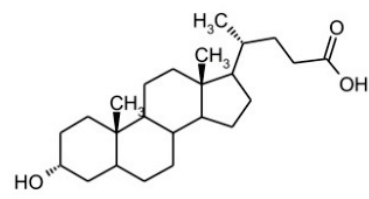

lithocholic acid (LCA)

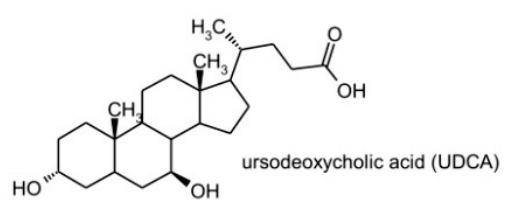

Fig. 1. Unconjugated primary and secondary bile acids in humans.

In agreement with above mentioned physiological roles of BA, some BA may be also exploited or tested as therapeutic agents, mostly in cholestatic liver diseases, inflammatory bowel disease (Gadaleta et al. 2010), diabetes mellitus and metabolic disorders (part Therapeutic use of BA).

This review summarizes the importance of BA as important regulators of various homeostatic mechanisms with detailed focus on cytochrome P450 (CYP) enzymes.

\section{Synthesis, metabolism and circulation of bile acids}

BA are synthetized in the liver from cholesterol ("classical pathway") in multiple steps catalyzed via CYPs, hydroxy-delta-5-steroid dehydrogenase (HSD3B7), $\Delta^{4-3}$-oxosteroid-5 $\beta$-reductase (AKR1D1) and $3 \alpha$-hydroxysteroid dehydrogenase (AKR1C4) to form $5 \beta$-cholestan- $3 \alpha, 7 \alpha, 12 \alpha$-triol. Biosynthetic pathway of CDCA leads directly to $5 \beta$-cholestan- $3 \alpha, 7 \alpha$-diol via AKR1D1 and AKR1C4. Subsequently, those by products are hydroxylated in the position 27 and the hydroxylic group is then oxidized to aldehydic and carboxylic group. The products are further ligated to coenzyme A (CoA) and the side chain is shortened by $\beta$-oxidation to release propionyl-CoA and cholyl-CoA or chenodeoxycholylCoA. Under physiological conditions, CA and CDCA occurs as $\mathrm{Na}^{+}$salts (,bile salts") (Chiang 2004). Then, primary BA are conjugated with glycine and taurine. UDCA is 7-epimer of chenodeoxycholic acid and therefore is more hydrophilic than its structural analogue CDCA (Fig. 1) and forms about $4 \%$ of BA pool (Roma et al. 2011). Hydroxylation in the positions $6 \alpha / \beta$ or $7 \beta$ increases water solubility and decrease toxicity of BA (Chiang 2013).

Apart from this "classic pathway", alternative ("acidic") biosynthetic pathway exists in humans, which forms less than $10 \%$ of total BA. In this pathway, which is believed to occur also in extrahepatic tissues, cholesterol is hydroxylated by series of steps (e.g. CYP27A1, CYP46A1, HSD3B7, 3ßHSD), but finally has to be transported into the liver to complete synthesis of CA and CDCA (Chiang 2004, 2009; Russell 2000).

Conjugated BA are stored in gall bladder and secreted into the duodenum in response to ingestion of meal. Then, about $95 \%$ of BA is reabsorbed in ileum, mostly by apical $\mathrm{Na}^{+}$-dependant bile salt transporter (SLC10A2 or ASBT) (Camilleri and Gores 2015b). Resorbed BA are transported to the liver in blood through vena portae (Chiang 2013). BA which are not reabsorbed undergo deconjugation and dehydroxylation by intestinal flora to form secondary BA, LCA, and DCA, of which the most is excreted in faeces (Chiang 2009, Chiang 2013).

\section{Bile acids - ligands of nuclear receptors}

For many years, BA were thought to be fat emulsifiers and digestive surfactants as the only function of 
the BA in the human body. However, recent observations in the last decade documented that BA are involved in the regulation of more complex processes including bile production, glucose and lipid metabolism, and in the modulation of immune response (Renga et al. 2013, Trauner et al. 2010, Claudel et al. 2005). The regulatory role of BA is a result of their interaction with various types of receptors including both intracellular nuclear receptors (NR) and cell surface membrane receptors (MR). BA acids vary in their ability to bind and activate different types of receptors. CDCA together with DCA are the most potent activators of FXR (Parks et al. 1999, Makishima et al. 1999), while LCA is the most potent activator of membrane G-protein coupled receptor TGR5 (Sato et al. 2008). Except of regulation of energy metabolism and immune system reactions, stimulation of different NRs and MRs by BA helps to maintain bile acid homeostasis via targeting the processes of their synthesis, release, reabsorption or metabolism (Copple and Li 2016).
BA are activators/ligands of various NRs, at least their ability to influence FXR, pregnane $\mathrm{X}$ receptor (PXR), vitamin D receptor (VDR), and liver $\mathrm{X}$ receptor (LXR) is well documented (Table 1, Chiang 2013, Song and Liao 2000). On the other hand some NRs which do not interact with BA, such as constitutive androstane receptor (CAR), can significantly influence the metabolism of BA. Most of these NRs are highly expressed in tissues exposed to high levels of BA like are liver or intestine (Kliewer et al. 1998, Forman et al. 1995, Gascon-Barré et al. 2003, Qatanani and Moore 2005).

NRs are ligand activated transcription factors consisting of N-terminal DNA binding domain (DBD) necessary to recognize the DNA response element in the target genes and C-terminal ligand-binding domain (LBD) interacting usually with small hydrophobic molecules. Activation of NRs by bile acids results in restriction of $\mathrm{BA}$ synthesis and increase of their degradation and excretion.

Table 1. Bile acids, their derivatives and metabolites as ligands of nuclear receptors.

\begin{tabular}{|c|c|c|}
\hline Receptor & Ligands & Reference \\
\hline \multirow[t]{3}{*}{$F X R$} & $\mathrm{CDCA}>\mathrm{DCA} \approx \mathrm{LCA}>\mathrm{CA}>\mathrm{UDCA}$ & Makishima et al. 1999, Parks et al. 1999) \\
\hline & Bile alcohols, $6 \alpha$-ethylCDCA & Pellicciari et al. 2002 \\
\hline & $\begin{array}{l}5 \beta \text {-cholanoic acid, } 5 \beta \text {-norcholanoic acid, and } \\
5 \alpha \text {-cholanoic acid }\end{array}$ & Sepe et al. 2016 \\
\hline \multirow[t]{2}{*}{$P X R$} & 3-keto-LCA $>$ LCA $>$ CDCA $>$ DCA $>C A$ & Taudinger et al. 2001 \\
\hline & $7 \alpha-\mathrm{OH}-4$-cholesten-3-one & Goodwin et al. 2003 \\
\hline$V D R$ & LCA, 3-keto LCA & Makishima et al. 2002 \\
\hline \multirow[t]{3}{*}{$L X R$} & Cholestenoic acid & Song and Liao 2000 \\
\hline & $6 \alpha$-hydroxylated BA & Song et al. 2000 \\
\hline & Oxysterols & Janowski et al. 1996, Lehmann et al. 1997 \\
\hline
\end{tabular}

\section{Farnesoid X receptor (FXR; NR1H4)}

There are two genes $(F X R \alpha$ and $F X R \beta)$ coding the FXR. FXR $\beta$ represents a functional $\mathrm{NR}$ in mammalian species except of primates and humans, where the gene encodes the non-functional protein (Otte et al. 2003). FRX $\alpha$ encodes four isoforms of FXR different either in the use of promoters or in alternative splicing (Zhang et al. 2003). The structure of FXR corresponds with the general structure of NR with the LBD allowing receptor heterodimerization with retinoid $\mathrm{X}$ receptor (RXR) and interactions with co-regulators. After interaction with agonist, FXR binds with FXR response elements as heterodimer $\mathrm{FXR} / \mathrm{RXR}$ or as a monomer and regulates the gene expression (Ding et al. 2015).

FXR is mainly found in hepatocytes, enterocytes (Forman et al. 1995) and acts as a sensor in the enterohepatic system regulating BA homeostasis. BA are potentially toxic and their levels have to be strictly controlled. In the hepatocytes, FXR controls BA synthesis (via CYP7A1, CYP8B1), sinusoidal uptake, and canalicular secretion of BA. In the intestine, FXR regulates the absorption, trafficking from the apical to the basolateral membrane and basolateral efflux (Modica and Moschetta 2006). FXR plays a protective role against BA toxicity by feedback inhibition of $C Y P 7 A 1, C Y P 8 B 1$, and 
CYP27A1 expression (Copple and $\mathrm{Li}$ 2016). The regulation of expression of above mentioned genes is not direct, but mediated via small heterodimer partner (SHP) interacting with liver-related homolog-1 (LRH-1) or hepatocyte nuclear factor $4 \alpha$ in the liver (Kwong et al. 2015) and fibroblast growth factor 19 (FGF19) binding to FGF receptor 4 in the intestine (Kir et al. 2011).

BA can activate the FXR in their free and conjugated forms. The most powerful ligand of FXR is CDCA with the $\mathrm{EC}_{50}$ approximately $10 \mu \mathrm{mol} / 1$ (Ding et al. 2015). Other endogenous $\mathrm{BA}$ bind to FRX with lower affinity as follows: $\mathrm{CDCA}>\mathrm{DCA} \approx \mathrm{LCA}>\mathrm{CA}>\mathrm{UDCA}$ (Makishima et al. 1999, Parks et al. 1999).

\section{Pregnane X receptor (PXR; NR1I2)}

PXR acts mainly as a xenobiotic sensor. It is activated by steroidal substances including glucocorticoids and its main role is to form a barrier protecting inner environment from xenobiotics. Therefore, its highest expression was found within liver and intestine (Kliewer et al. 1998).

The PXR LBC is substantially larger than in other NRs and is poor in the number of polar groups. Such characteristic explains the high promiscuity and variability of its ligands (Handschin and Meyer 2005). PXR is activated for example by glucocorticoids, steroids, macrolide antibiotics, antifungals, and some herbal extracts (Jones et al. 2000, Lehmann et al. 1998, Ihunnah et al. 2011). From bile acids the most potent ligand of PXR is LCA with the $\mathrm{EC}_{50} \sim 10 \mu \mathrm{mol} / 1$ (Staudinger et al. 2001). It is questionable whether BA can activate the receptor under physiologic conditions when their plasma levels are below $100 \mathrm{nmol} / \mathrm{l}$. It is hypothesized, that sufficient concentration can be reached after rupture of intrahepatic bile duct in cholestasis, when PXR can increase BA clearance by $C Y P 3 A$ induction and decrease its biosynthesis by suppression of $C Y P 7 A 1$ expression (Copple and $\mathrm{Li}$ 2016). After binding the ligand it is translocated into nucleus and associated with RXR to form a heterodimer activating gene transcription.

The range of regulated genes is wide including many of phase I (Table 2) and II enzymes, or uptake and efflux transporters. The role of PXR in the expression of drug metabolizing enzymes is well documented by the study of Kandel et al. (2016), who treated human hepatocytes from 6 donors with rifampicin, a well proved human PXR agonist. Results confirmed the protective role of PXR against BA toxicity as expression of most of the CYP biotransformation enzymes genes were increased (Table 2) while the CYP7A1, involved in BA synthesis, was decreased to 0.32 -fold in comparison to control (Kandel et al. 2016).

Table 2. The role of NRs in the regulation of CYP genes expression.

\begin{tabular}{|c|c|c|c|c|c|c|}
\hline \multirow{2}{*}{ CYP } & \multicolumn{5}{|c|}{ Receptor } & \multirow{2}{*}{ Reference } \\
\hline & FXR & PXR & VDR & CAR & LXR & \\
\hline $1 A 1$ & & & & $\uparrow$ & & 1 \\
\hline $1 A 2$ & & & & $\uparrow$ & & 1 \\
\hline $2 A 6$ & & & $\uparrow$ & $\uparrow$ & & 1,2 \\
\hline $2 A 7$ & & & & $\uparrow$ & & 1 \\
\hline $2 A 9$ & & & $\uparrow$ & & & 2 \\
\hline $2 A 13$ & & & & $\uparrow$ & & 1 \\
\hline $3 A 1$ & & $\uparrow$ & & & & 3 \\
\hline $3 A 2$ & & $\uparrow$ & & & & 3 \\
\hline $3 A 4^{*}$ & $\uparrow$ & $\uparrow$ & $\uparrow$ & $\uparrow$ & & $1,4,5,6,7,8,9$ \\
\hline $3 A 7$ & & $\uparrow$ & & $\uparrow$ & & 1 \\
\hline $7 A 1$ & $\downarrow$ & $\downarrow$ & $\downarrow$ & & $\uparrow$ & $1,10,11,12,13$ \\
\hline $27 A 1$ & $\downarrow$ & & & & & 10 \\
\hline $2 B 6$ & & $\uparrow$ & & $\uparrow$ & & $1,4,9,14$ \\
\hline $2 B 7$ & & $\uparrow$ & & $\uparrow$ & & 1 \\
\hline $8 B 1$ & $\downarrow$ & & & $\uparrow$ & & 10 \\
\hline $2 C 8$ & & $\uparrow$ & & $\uparrow$ & & 1 \\
\hline $2 C 9$ & & $\uparrow$ & & $\uparrow$ & & 1,4 \\
\hline $2 E 1$ & & & & $\downarrow$ & & 1 \\
\hline
\end{tabular}

$\uparrow$ - expression increased, $\downarrow$ - expression decreased, ${ }^{*}$ - human CYP3A4 is orthologue of mice CYP $3 A 11$, therefore results from animal models are represented as change in CYP3A4 expression. Ref.: 1 - Kandel et al. 2016, 2 - Drocourt et al. 2002, 3 - Kliewer et al. 1998, 4 - Drocourt et al. 2001, 5 - Gnerre et al. 2004, 6 - Goodwin et al. 2002, 7 - Goodwin et al. 2000, 8 - Makishima et al. 2002, 9 - Sberna et al. 2011, 10 - Eloranta and KullakUblick 2005, 11 - Han et al. 2010, 12 - Lehmann et al. 1997, 13 - Staudinger et al. 2001, 14 - Xie et al. 2000.

\section{Vitamin D receptor (VDR; NR1I1)}

In spite of the fact that hepatocytes do not express VDR, its significant levels are found in nonparenchymal liver cells such as Kupffer cells or sinusoidal endothelial cells (Gascon-Barré et al. 2003). The typical ligand of VDR is cholecalciferol, while most of the BA including CDCA, CA, DCA, or muricholic acid does not activate VDR. Similarly to ligands of PXR, VDR can be activated by LCA and its metabolite 3-ketoLCA with the $\mathrm{EC}_{50} \approx 8 \mu \mathrm{M}$ and $3 \mu \mathrm{M}$, respectively (Makishima et al. 2002). It could be of clinical importance that therapeutically used UDCA can be converted to LCA (VDR and PXR agonist) by intestinal microflora (Xie et al. 2001, Staudinger et al. 2001). 
The role of VDR to promote calcium and phosphate absorption is well known. Its protective role against BA toxicity similar to PXR or against infection of bile duct was documented in the past decade. Stimulation of VDR by both vitamin D and LCA induces production of antimicrobial peptide cathelicidin in the bile duct epithelial cells (D'Aldebert et al. 2009). Both ligands can also increase the expression of CYP3A4 leading to elevated BA clearance (Makishima et al. 2002) while the expression of $C Y P 7 A 1$ can be reduced through VDR activation (Han et al. 2010). Moreover, there is documented interaction between VDR and $\operatorname{LXR} \alpha$ with antagonizing effects on the CYP7A gene, too (Jiang et al. 2006).

\section{Liver X receptor alpha (LXR $\alpha$; NR1H3)}

This NR can be found in the tissues with high metabolic activity such as liver, small intestine, kidney or adipocytes (Sato and Kamada 2011), in comparison to LXR $\beta$, which is ubiquitously expressed in all tissues (Teboul et al. 1995). LXR binds to its responsive elements as heterodimer associated with RXR and its influence on gene expression is tissue specific (Moschetta 2015).

Its known endogenous ligands are oxysterols and its physiologic role is the regulation of cholesterol, fatty acid, and glucose homeostasis (Zelcer and Tontonoz 2006). Oppositely to other mentioned NR, LXR activation leads to increased activity of $C Y P 7 A 1$, thus the formation of BA is increased. Together with increased cholesterol transport to bile via specific transporters and restriction of its absorption from intestine, the level of total plasma cholesterol is decreased. However, reduction in cholesterol levels via activation of LXR is associated with fatty liver and hypertriglyceridemia development (Moschetta 2015).

LXR is activated by cholestenoic acid with $\mathrm{ED}_{50}$ of $200 \mathrm{nmol} / \mathrm{l}$ (Song and Liao 2000) and also by different oxysterols (Lehmann et al. 1997, Janowski et al. 1996) and $6 \alpha$-hydroxylated BA (Song et al. 2000) within the range of their physiologic levels.

\section{Constitutive androstane receptor (CAR; NR113)}

CAR is closely related to PXR, this NR acts similarly as xenobiotic sensors which regulate expression of genes significant for biotransformation and excretion of exogenous compounds. Both receptors are activated by toxic derivatives of endobiotic metabolism, too. However, CAR seems to be more sensitive to endogenous stimuli (Bing et al. 2014). Typical exogenous ligands of CAR represent phenobarbital, 3,3',5,5'-Tetrachloro-1,4-bis(pyridyloxy)benzene

(TCOBOP) (Timsit and Negishi 2007). When activated, it is translocated into nucleus via protein phosphate PP2A and association with RXR precede to binding to DNA (Timsit and Negishi 2007). BA do not seem to be direct ligands of CAR, nevertheless activation of this receptor increases activity of enzymes producing more hydrophilic and thus less hepatotoxic metabolites of BA (Beilke et al. 2009) and activates their excretion from hepatocytes (Wagner et al. 2005).

The genome-wide screening in the liver cells of human donors treated by CAR prototype ligand CITCO (6-(4-Chlorophenyl)imidazo[2,1-b][1,3]thiazole-5-carbaldehyde O-(3,4-dichlorobenzyl)oxime) revealed $11 \mathrm{CYP}$ genes among top 25 influenced genes. In all cases CITCO increased gene expression in the range between 1.28- and 2.19-fold in ascending order as follows: $2 C 9<$ $1 A 2<3 A 7<3 A 4<2 C 8<2 A 6<2 A 13<1 A 1<2 A 7<2 B 6<2 B 7$ (Kandel et al. 2016). On the other hand, $C Y P 2 E 1$ was downregulated with 0.86-fold decrease of its expression (Kandel et al. 2016).

Besides binding to nuclear receptors, BA are also ligands of other types of receptors, including membrane $G$ protein-coupled receptors. The first G-protein coupled receptor known to interact with BA was TGR5, GP-BAR1, or M-BAR. This receptor is widely distributed in different tissues and stimulation leads to different effects depending on the tissue and signalling cascade mediating the signal (Duboc et al. 2014). TGR5 is involved in energy metabolism; it protects liver and intestine from inflammation and steatosis, and improves insulin sensitivity (Chiang 2013, Li and Chiang 2015). The influence of some of BA on the immune response is also essential in their therapeutic effect in cholestatic liver diseases (Poupon 2012, Poupon 2014). This effect is in case of UDCA probably mediated by interaction with toll-like receptors TLR4 and TLR9 and glucocorticoid receptors (Poupon 2012).

\section{Regulation of CYP enzymes involved in the metabolism of bile acids}

The synthesis of BA is limited mainly through activity of cholesterol $7 \alpha$-hydroxylase (CYP7A1), which is believed to be the only rate-limiting step in BA synthesis (Chiang 2013). The protein content and metabolic activity of CYP7A1 is regulated by variety of 
Table 3. Bile acids as regulators of CYP expression.

\begin{tabular}{|c|c|c|c|c|c|c|c|c|c|c|c|c|}
\hline \multirow{2}{*}{ Bile acid } & \multicolumn{12}{|c|}{ CYP } \\
\hline & 1A1 & $1 \mathrm{~A} 2$ & 3A1 & 3A2 & $3 \mathbf{A 4}^{+}$ & $\mathbf{3 A} 7$ & 3A9 & 7A1 & 27A1 & $2 \mathrm{B6}^{+}$ & $2 \mathrm{C} 8$ & 2E1 \\
\hline$C D C A$ & $\downarrow^{7}$ & $\downarrow^{7}$ & $\uparrow^{5,6} \downarrow^{6^{*}}$ & $\uparrow^{5} \downarrow^{6 *}$ & $\uparrow^{3,6} \downarrow^{7}$ & & $\downarrow^{6^{*}}$ & $\downarrow^{1,7}$ & & & $\downarrow^{7}$ & $\downarrow^{7}$ \\
\hline$D C A$ & & & & & $\uparrow^{3}$ & & & $\downarrow^{1}$ & & & & \\
\hline$U D C A$ & & & & & $\uparrow^{2,3}$ & & & $\downarrow^{1,2}$ & & $\uparrow^{2}$ & & \\
\hline$L C A$ & & & $\uparrow^{5}$ & $\uparrow^{5}$ & & & & $\downarrow^{1}$ & & & & \\
\hline$C A$ & & & & & $\uparrow^{2,3}$ & & & $\downarrow^{2}$ & & $\uparrow^{2}$ & & \\
\hline TUDCA & & & & & $\uparrow^{3}$ & & & & & & & \\
\hline$T D C A$ & & & & & & & & & $\downarrow^{4}$ & & & \\
\hline
\end{tabular}

$\uparrow$ - expression increased, $\downarrow$ - expression decreased, ${ }^{1}$ - Roma et al. 2011, ${ }^{2}$ - Zollner et al. 2006, ${ }^{3}$ - Schuetz et al. 2001, ${ }^{4}-$ Rao et al. 1999, ${ }^{5}$ - Khan et al. 2010, ${ }^{6}$ - Khan et al. 2009, ${ }^{7}$ - Krattinger et al. 2016. ${ }^{*}$ - only in rat liver, ${ }^{+}$- human CYP3A4 and CYP2B6 are orthologue of mice CYP3A11 and CYP2B10, respectively. Therefore results from animal models are represented as change in CYP3A4 and CYP2B6 expression.

factors. CYP7A1 metabolic activity is limited mainly by availability of its substrate cholesterol. Feeding the experimental animals with cholesterol lead to increase expression of CYP7A1, suggesting the stimulatory effect of substrate ("Km effect") on CYP7A1 (Chiang 2013). On the other hand, negative feedback exists and most of BA are negative regulators of CYP7A1 (Gupta et al. 2001). CDCA, DCA and with much lesser potency also other BA, such as UDCA and LTA, inhibit transcription of CYP7A1 gene. Minor BA, UDCA, which is used therapeutically, increases expression of murine $C Y P 3 A 11$, $C Y P 2 B 10$ and human $C Y P 3 A 4$ - these enzymes catalyze hydroxylation of primary BA towards less toxic (hydrophilic) BA (Roma et al. 2011, Schuetz et al. 2001).

As mentioned above, BA are ligands of several $\mathrm{NR}$, including FXR and it seems that BA downregulate $C Y 7 A 1$ probably through activation of $\mathrm{RXR} \alpha / \mathrm{FXR}$ (Chiang 2013). FXR decreases CYP7A1 expression by several indirect mechanisms, by induction of SHP, which in turn inhibits transactivation of $C Y P 7 A 1$ and $C Y P 8 B 1$ by hepatocyte nuclear factor $4 \alpha \mathrm{HNF} 4 \alpha$ ) and liver-related homolog-1 (LRH-1). This is in line with finding of Peng et al. (2016), who reported that CYP7A1 is upregulated in young FXR nullizygous mice.

Moreover, activation of FXR further decreases intracellular BA content by increase of expression of canalicular BSEP (bile salt efflux pump, ABCB11). These feedback mechanisms seem to protect inner environment of hepatocytes from BA toxicity and liver damage. Taurodeoxycholic acid also downregulates CYP27A1 via activation of HNF1 $\alpha$ (Rao et al. 1999).

The regulation of BA synthesis and metabolism seems to be very complex and some pathways are anticipatory, since activation of VDR may trigger decrease of SHP and this leads to induction of CYP7A1 (Chow et al. 2014). The expression of VDR itself in rat ileum and liver is regulated (among others) by some of BA (at least by CDCA), but not LCA. The VDR activation by 1,25-dihydroxycholecalciferol or LCA then leads to increase in transcription of $C Y P 3 A 1$ and $C Y P 3 A 2$ genes as well as CDCA treatment. However, when combined together with LCA the expression of CYP3A1 and $C Y P 3 A 2$ is reduced (Khan et al. 2010). It was also reported by the same team of authors that CDCA decreases expression of CYP3A1, CYP3A2, and CYP3A9 mRNA in rat liver, whereas the expression of $C Y P 3 A 1$ in the rat ileum is increased and CYP3A2 and CYP3A9 are not influenced within the whole rat intestine (Khan et al. 2009). This means that unlike UDCA, CDCA could decrease the metabolism and increase the liver toxicity of hydrophobic BA (Khan et al. 2010). Moreover, the same team of authors reported that CDCA induced CYP3A4 in human liver (Khan et al. 2009). In another study with the primary culture of human hepatocytes, CDCA decreased expression of $C Y P 3 A 4$, CYP7A1, CYP2C8, CYP1A1, CYP2E1 and CYP1A2 genes after 48 hours of incubation, as well as it decreased expression of the $A H R$ and PPAR $\gamma$ gene (Krattinger et al. 2016). The overview of BA influence on CYP enzymes is summarized in the Table 3 . The results of experiments focused on the regulatory role of BA in the CYP expression seem to be highly variable and dependent on the model used. Moreover, the effects of hydrophobic and hydrophilic BA may differ, as there are differences in 
their selectivity and affinity to nuclear receptors (Table 1). This is also resembled by different clinical effects of DCA and CA on one hand and UDCA, TUDCA and nor-UDCA on the other hand. While CA and CDA appear to be hepatotoxic, UDCA prevents from liver damage. Surprisingly, the genetic polymorphisms of CYP7A1 do not seem to influence the production of BA (Xiang et al. 2012).

Other endogenous regulators seem to play a significant role in BA synthesis, such as blood glucose levels, insulin, thyroid hormone, glucocorticoids and glucagon (Siljevik Ellis 2006, Twisk et al. 1995, Chiang 2009, Xiao et al. 2016). Glucose increases both CYP7A1 transcription (Li et al. 2010) and CYP7A1 metabolic activity by histone acetylation of gene promoter. The latter mechanism is also mediated by insulin ( $\mathrm{Li}$ et al. 2012). Glucagon inhibits BA synthesis via block of CYP7A1 expression (Song and Chiang 2006). In overall, fasting state seem to downregulate CYP7A1, while elevated glucose and insulin seems to increase expression or metabolic activity of CYP7A1 (Chiang 2009, Chiang 2013).

\section{Bile acids as regulators of CYP enzymes involved in the metabolism of xenobiotics}

Through activation of FXR and PXR, BA are regulating rate-limiting step in their biosynthetic pathway (CYP7A1), as well as several transporters involved in BA elimination from hepatocytes, as mentioned above.

BA may also influence CYP enzymes, which are primarily involved in the drug metabolism, such as CYP3A4, CYP2C8, CYP2E1 or CYP1A2.

Although PXR and CAR are primary regulators of CYP enzymes, other nuclear receptors of different types are also known to be involved in their regulation.

With respect to the proposed binding ability to the nuclear receptors, namely FXR, it is not surprising that BA may induce expression of CYP3A4 (Schuetz et al. 2001), SULT2A1 and UGT2B4 genes (Poupon 2012) and increase CYP3A4 metabolic activity (Schuetz et al. 2001).

In particular, FXR nullizygous mice exhibit downregulation of bile salt export pump and thus increase hepatocellular BA content, which in turn, may activate PXR and upregulate CYP3A (involved in their metabolism), but also $C Y P 2 B$ and some $A B C$ transporters (Schuetz et al. 2001). It is also note of worth, that BA are not equipotent ligands of FXR (Table 1). Hydrophilic BA are not considered to be agonists of FXR (Chiang, 2013) and sometimes are reported to be partial agonists, and sometimes also partial antagonists of FXR, such as UDCA (Modica et al. 2010).

It was reported that UDCA may induce the enzymes of CYP3A subfamily (Schuetz et al. 2001) and thus decrease concentrations of substrates of CYP3A4 (such as cyclosporine A (CsA)) after UDCA treatment (Yan et al. 2008, Becquemont et al. 2006, Kurosawa et al. 2009, Uchida et al. 2014).

Interestingly, the rate of CsA elimination was not changed (Caroli-Bose et al. 2000), what implies for decreased bioavailability through induction of intestinal CYP3A4 and P-glycoprotein by activation of PXR (Schuetz et al. 2001). PXR is known as potent inducer of phase I metabolic enzymes, phase II conjugation enzymes and phase III drug transporters (Chiang 2013). Among BA, both taurine-conjugate of UDCA (TUDCA) and UDCA were reported to be the most effective inducers of CYP3A4 in primary human hepatocytes (Schuetz et al. 2001) which corresponds with their ability to decrease toxicity of more hydrophobic BA.

Information on the influence of UDCA on bioavailability of CsA are inconsistent and controversial, since there were published studies documenting decreased dosing of CsA when combined with UDCA, when AUC of CsA were increased twice (Gutzler et al. 1992). Similarly, the bioavailability of CsA was increased with either combination with TUDCA or CsA-TUDCA micellar solution (Balandraud-Pieri et al. 1997). This report may be explained in part by effect of excipient-based increase ion CsA bioavailability, since other micellar dispersions of CsA may also increase the bioavailability and AUC of CsA (Balandraud-Pieri et al. 1997).

\section{Therapeutic use of BA}

Dried bile of Chinese black bear was used as a remedy already during the dynasty of Tang in China (approximately 600-900 A.D.) (Guarino et al. 2013). Evidence-based use of bile acids as drugs dates about 30 years back (Beuers et al. 2015). In particular, CDCA was utilized as a treatment for gallstone dissolution, which was later displaced by UDCA due to the better safety profile and efficacy. CDCA caused diarrhea, increased serum total cholesterol and LDL-cholesterol, among other adverse effects (American Society of Health System Pharmacists 2016a). UDCA is currently the only drug approved by FDA for the treatment of primary 
biliary cirrhosis (PBC, stage I. and II.) (Roma et al. 2011). UDCA delays progression and need for liver transplantation, increases survival and is well tolerated in $\mathrm{PBC}$ at the doses of $10-20 \mathrm{mg} / \mathrm{kg} /$ day (American Society of Health System Pharmacists 2016b, Poupon 2014, Roma et al. 2011). In some countries, UDCA is also recommended in primary sclerosing cholangitis (PSC) but evidence on benefit from treatment with UDCA is not as convincing as in PBC. Nevertheless, UDCA is reported to improve biochemical characteristics of disease, ameliorate inflammatory component of the disease, but it probably does not influence overall survival, liver histology nor time to the transplantation at the doses of $10-15 \mathrm{mg} / \mathrm{kg} / \mathrm{day}$ (EASL 2009). UDCA is also registered for the dissolution of radiolucent, noncalcified gallbladder stones smaller than $20 \mathrm{~mm}$ in diameter at the doses of $10-114 \mathrm{mg} / \mathrm{kg} /$ day (American Society of Health System Pharmacists 2016b). UDCA is also recommended in the treatment of intrahepatal cholestasis in pregnancy $(10-20 \mathrm{mg} / \mathrm{kg} /$ day $)$. It alleviates pruritus and improves liver biochemical parameters in up to $80 \%$ of patients (European Assoc Study 2009, Gabzdyl and Schlaeger 2015). Another use of UDCA is cystic fibrosis liver disease (CFLD, syn. CFALD - Cystic Fibrosis Associated Liver Disease, syn. CFAHD - Cystic Fibrosis Associated Hepatobiliary Disorders). UDCA improves biochemical parameters in cystic fibrosis patients, but not overall survival (Staufer et al. 2014). Concerning off-label use, UDCA is recommended by European Society for Blood and Marrow Transplantation (ESBMT) as protective agent in Hepatic Veno-Occlusive Disease after hematopoietic stem cell transplantation $(R R=0.34) \quad$ (Dalle and Giralt 2016). Due to the hepatoprotective effect of UDCA, there are some reports that UDCA improves biochemical parameters in nonalcoholic steatohepatitis (NASH), notably in higher doses (Xiang et al. 2013), but in overall there is not enough evidence for routine use of UDCA in NASH (Ratziu 2012, Georgescu and Georgescu 2007). UDCA in low doses may also prevent from colorectal cancer in patients with concomitant inflammatory bowel disease and PSC (Singh et al. 2013).

Some other derivatives of natural BA - "bile mimetics" - in particular FXR and TGR5 agonists, such as nor-UDCA and obeticholic acid, have been suggested to treat cholestatic liver disease (Poupon 2012, Adorini et al. 2012). Obeticholic acid (6a-ethyl-chenodeoxycholic acid) is a semisynthetic derivative of CDCA and potent FXR agonist (Neuschwander-Tetri et al. 2015). It was used in the treatment of PBC and NASH in patients non responding to UDCA (Camilleri and Gores 2015). Obeticholic acid also improved liver histology in NASH patients, but $23 \%$ of the patients developed pruritus compared to $6 \%$ in placebo group (Neuschwander-Tetri et al. 2015). Moreover, obeticholic acid (25 mg/day) improved liver enzymes, increased low density lipoproteins and decreased markers of fibrosis in patients with type II diabetes mellitus and non-alcoholic fatty liver disease (NAFLD) (Mudaliar et al. 2013). In another study, increase of total cholesterol with simultaneous decrease of HDL cholesterol was reported upon obeticholic acid treatment (Neuschwander-Tetri et al. 2015).

BA and BA sequestrants are currently investigated as possible adjustment to the treatment of diabetes mellitus (notably Type II) due to their ability to increase insulin sensitivity, and decrease gluconeogenesis (in particular through increase of glucagon like peptide 1) (Camilleri and Gores 2015).

\section{Conclusions}

BAs are essential physiological factors preserving homeostasis through their influence on nutrition, metabolism and excretion of both endo- and xenobiotics and their metabolites. BAs have also an important role in pathogenesis of cholestatic diseases and drug induced liver injury. Some of BA, their analogues and so called bile mimetics seem to be promising drugs. Apart of the effects of lipid absorption and xenobiotic excretion based on physico-chemical properties of BA, most of their regulatory and signalling properties are mediated through the nuclear receptors FXR, PXR CAR, LXR and VDR, as well as membrane bound receptors TGR5 and S1PR2 (Copple and Li 2016). The physiological role of interaction of BA with NRs is probably to decrease production of toxic hydrophobic BA and to increase their metabolic turnover towards polar and hydrophilic BA, to increase their excretion and thus decrease their toxicity in the hepatocytes. By this, the activity of some drug-metabolizing CYPs is also influenced since these are regulated by the same NRs, what could have clinically relevant consequences in cholestatic diseases or during the treatment with BA or their derivatives.

\section{Conflict of Interest}

There is no conflict of interest. 


\section{Acknowledgements}

This work was supported by the grant of Grant agency of the Czech Republic No. GA16-06106S and written at Masaryk university as a part of the project „Experimental pharmacological development in neuropsychopharmaco- logy and oncology“ number MUNI/A/1284/2015 with the support of the Specific University Research Grant, as provided by the Ministry of Education, Youth and Sports of the Czech Republic in the year 2016.

\section{References}

ADORINI L, PRUZANSKI M, SHAPIRO D: Farnesoid X receptor targeting to treat nonalcoholic steatohepatitis. Drug Discov Today 17: 988-997, 2012.

American Society of Health System Pharmacists 2016a, Inc., DynaMed [Internet]. Ipswich (MA): EBSCO Information Services. 1995 - Record No. 900215, Chenodiol; [updated 2016 Jan 19, 20.07. 2016]; Available from http://search.ebscohost.com/login.aspx?direct=true \&db=dnh\&AN=900215\&site=dynamed-live\&scope=site.

American Society of Health System Pharmacists 2016b, Inc., DynaMed [Internet]. Ipswich (MA): EBSCO Information Services. 1995 - Record No. 526120, Ursodiol; [updated 2011 Jun 28, 20.07. 2016]; available from http://search.ebscohost.com/login.aspx?direct=true \&db=dnh\&AN=526120\&site=dynamed-live\&scope=site.

BALANDRAUD-PIERI N, QUENEAU PE, CAROLIBOSC FX, BERTAULTPERES P, MONTET AM, DURAND A, MONTET JC: Effects of tauroursodeoxycholate solutions on cyclosporin a bioavailability in rats. Drug Metab Dispos 25: 912-916, 1997.

BECQUEMONT L, GLAESER H, DRESCHER S, HITZL M, SIMON N, MURDTER T, HEINKELE G, HOFMANN U, SCHAEFER C, BURK O, VERSTUYFT C, EICHELBAUM M, FROMM M: Effects of ursodeoxycholic acid on P-glycoprotein and cytochrome P450 3A4-dependent pharmacokinetics in humans. Clin Pharmacol Ther 79: 449-460, 2006.

BEGLEY M, GAHAN CG, HILL C: The interaction between bacteria and bile. FEMS Microbiol Rev 29: 625-651, 2005.

BEILKE LD, ALEKSUNES LM, HOLLAND RD, BESSELSEN DG, BEGER RD, KLAASSEN CD, CHERRINGTON NJ: Constitutive androstane receptor-mediated changes in bile acid composition contributes to hepatoprotection from lithocholic acid-induced liver injury in mice. Drug Metab Dispos 37: 1035-1045, 2009.

BEUERS U, TRAUNER M, JANSEN P, POUPON R: New paradigms in the treatment of hepatic cholestasis: From UDCA to FXR, PXR and beyond. J Hepatol 62: 25-37, 2015.

BING Y, ZHU S, JIANG K, DONG G, LI J, YANG Z, YANG J, YUE J: Reduction of thyroid hormones triggers down-regulation of hepatic CYP2B through nuclear receptors CAR and TR in a rat model of acute stroke. Biochem Pharmacol 87: 636-649, 2014.

BURYOVA H, CHALUPSKY K, ZBODAKOVA O, KANCHEV I, JIROUSKOVA M, GREGOR M, SEDLACEK R: Liver protective effect of ursodeoxycholic acid includes regulation of ADAM17 activity. Bmc Gastroenterology 13: 2013.

CAMILlERI M, GORES G: Therapeutic targeting of bile acids. Am J Physiol Gastrointest Liver Physiol 309: G209-G215, 2015.

CAROLI-BOSE F, ILIADIS A, SALMON L, MACHERAS P, MONTET A, BOURGEON A, GARRAFFO R, DELMONT J, MONTET J: Ursodeoxycholic acid modulates cyclosporin A oral absorption in liver transplant recipients. Fundam Clin Pharmacol 14: 601-609, 2000.

CENTUORI S, MARTINEZ J: Differential regulation of EGFR-MAPK signaling by deoxycholic acid (DCA) and ursodeoxycholic acid (UDCA) in colon cancer. Dig Dis Sci 59: 2367-2380, 2014.

CHIANG JYL: Regulation of bile acid synthesis: pathways, nuclear receptors, and mechanisms. J Hepatol 40: 539-551, 2004.

CHIANG JYL: Bile acids: regulation of synthesis. J Lipid Res 50: 1955-1966, 2009.

CHIANG JYL: Bile acid metabolism and signaling. Compr Physiol 3: 1191-1212, 2013. 
CHOW ECY, MAGOMEDOVA L, QUACH HP, PATEL R, DURK MR, FAN J, MAENG H-J, IRONDI K, ANAKK S, MOORE DD, CUMMINS CL, PANG KS: Vitamin D receptor activation down-regulates the small heterodimer partner and increases CYP7A1 to lower cholesterol. Gastroenterology 146: 1048-1605, 2014.

CLAUDEL T, STAELS B, KUIPERS F: The Farnesoid X receptor: a molecular link between bile acid and lipid and glucose metabolism. Arterioscler Thromb Vasc Biol 25: 2020-2030, 2005.

CLAUDEL T, ZOLLNER G, WAGNER M, TRAUNER M: Role of nuclear receptors for bile acid metabolism, bile secretion, cholestasis, and gallstone disease. Biochim Biophys Acta 1812: 867-878, 2011.

COPPLE BL, LI T: Pharmacology of bile acid receptors: Evolution of bile acids from simple detergents to complex signaling molecules. Pharmacol Res 104: 9-21, 2016.

D'ALDEBERT E, BIYEYEME BI MVE MJ, MERGEY M, WENDUM D, FIRRINCIELI D, COILLY A, FOUASSIER L, CORPECHOT C, POUPON R, HOUSSET C, CHIGNARD N: Bile salts control the antimicrobial peptide cathelicidin through nuclear receptors in the human biliary epithelium. Gastroenterology 136: 1435-1443, 2009.

DALLE JH, GIRALT SA: Hepatic veno-occlusive disease after hematopoietic stem cell transplantation: Risk factors and stratification, prophylaxis, and treatment. Biol Blood Marrow Transplant 22: 400-409, 2016.

DING L, YANG L, WANG Z, HUANG W: Bile acid nuclear receptor FXR and digestive system diseases. Acta Pharm Sin B 5: 135-144, 2015.

DROCOURT L, OURLIN JC, PASCUSSI JM, MAUREL P, VILAREM MJ: Expression of CYP3A4, CYP2B6, and CYP2C9 is regulated by the vitamin D receptor pathway in primary human hepatocytes. J Biol Chem 277: 25125-25132, 2002.

DROCOURT L, PASCUSSI JM, ASSENAT E, FABRE JM, MAUREL P, VILAREM MJ: Calcium channel modulators of the dihydropyridine family are human pregnane $\mathrm{X}$ receptor activators and inducers of CYP3A, CYP2B, and CYP2C in human hepatocytes. Drug Metab Dispos 29: 1325-1331, 2001.

DUBOC H, TACHÉ Y, HOFMANN AF: The bile acid TGR5 membrane receptor: from basic research to clinical application. Dig Liver Dis 46: 302-312, 2014.

ELORANTA JJ, KULLAK-UBLICK GA: Coordinate transcriptional regulation of bile acid homeostasis and drug metabolism. Arch Biochem Biophys 433: 397-412, 2005.

EASL Clinical Practice Guidelines: Management of cholestatic liver diseases. J Hepatol 51: 237-267, 2009.

FORMAN BM, GOODE E, CHEN J, ORO AE, BRADLEY DJ, PERLMANN T, NOONAN DJ, BURKA LT, MCMORRIS T, LAMPH WW, EVANS RM, WEINBERGER C: Identification of a nuclear receptor that is activated by farnesol metabolites. Cell 81: 687-693, 1995.

GABZDYL EM, SCHLAEGER JM: Intrahepatic cholestasis of pregnancy: a critical clinical review. J Perinat Neonatal Nurs 29: 41-50, 2015.

GADALETA RM, MIL SW, OLDENBURG B, SIERSEMA PD, KLOMP LW, ERPECUM KJ: Bile acids and their nuclear receptor FXR: Relevance for hepatobiliary and gastrointestinal disease. Biochim Biophys Acta 1801: 683-692, 2010.

GASCON-BARRÉ M, DEMERS C, MIRSHAHI A, NÉRON S, ZALZAL S, NANCI A: The normal liver harbors the vitamin D nuclear receptor in nonparenchymal and biliary epithelial cells. Hepatology 37: 1034-1042, 2003.

GEORGESCU EF, GEORGESCU M: Therapeutic options in non-alcoholic steatohepatitis (NASH). Are all agents alike? Results of a preliminary study. J Gastrointest Liver 16: 39-46, 2007.

GNERRE C, BLÄTTLER S, KAUFMANN MR, LOOSER R, MEYER UA: Regulation of CYP3A4 by the bile acid receptor FXR: evidence for functional binding sites in the CYP3A4 gene. Pharmacogenetics 14: 635-645, 2004.

GOODWIN B, GAUTHIER KC, UMETANI M, WATSON MA, LOCHANSKY MI, COLLINS JL, LEITERSDORF E, MANGELSDORF DJ, KLIEWER SA, REPA JJ: Identification of bile acid precursors as endogenous ligands for the nuclear xenobiotic pregnane X receptor. Proc Natl Acad Sci U S A 100: 223-228, 2003.

GOODWIN B, HODGSON E, D'COSTA DJ, ROBERTSON GR, LIDDLE C: Transcriptional regulation of the human CYP3A4 gene by the constitutive androstane receptor. Mol Pharmacol 62: 359-365, 2002. 
GOODWIN B, JONES S, PRICE R, WATSON M, MCKEE D, MOORE L, GALARDI C, WILSON J, LEWIS M, ROTH M, MALONEY P, WILLSON T, KLIEWER S: A regulatory cascade of the nuclear receptors FXR, SHP-1, and LRH-1 represses bile acid biosynthesis. Molecular Cell 6: 517-526, 2000.

GUARINO M, COCCA S, ALTOMARE A, EMERENZIANI S, CICALA M: Ursodeoxycholic acid therapy in gallbladder disease, a story not yet completed. World J Gastroenterol 19: 5029-5034, 2013.

GUTZLER F, ZIMMERMANN R, RING G, SAUER P, STIEHL A: Ursodeoxycholic acid enhances the absorption of cyclosporine in a heart-transplant patient with short bowel syndrome. Transplant Proc 24: 2620-2621, 1992.

HAN S, LI T, ELLIS E, STROM S, CHIANG JY: A novel bile acid-activated vitamin D receptor signaling in human hepatocytes. Mol Endocrinol 24: 1151-1164, 2010.

HANDSCHIN C, MEYER UA: Regulatory network of lipid-sensing nuclear receptors: roles for CAR, PXR, LXR, and FXR. Arch Biochem Biophys 433: 387-396, 2005.

IHUNNAH CA, JIANG M, XIE W: Nuclear receptor PXR, transcriptional circuits and metabolic relevance. Biochim Biophys Acta 1812: 956-963, 2011.

JANOWSKI BA, WILLY PJ, DEVI TR, FALCK JR, MANGELSDORF DJ: An oxysterol signalling pathway mediated by the nuclear receptor LXR alpha. Nature 383: 728-731, 1996.

JIANG W, MIYAMOTO T, KAKIZAWA T, NISHIO SI, OIWA A, TAKEDA T, SUZUKI S, HASHIZUME K: Inhibition of LXRalpha signaling by vitamin D receptor: possible role of VDR in bile acid synthesis. Biochem Biophys Res Commun 351: 176-184, 2006.

JONES SA, MOORE LB, SHENK JL, WISELY GB, HAMILTON GA, MCKEE DD, TOMKINSON NC, LECLUYSE EL, LAMBERT MH, WILLSON TM, KLIEWER SA, MOORE JT: The pregnane X receptor: a promiscuous xenobiotic receptor that has diverged during evolution. Mol Endocrinol 14: 27-39, 2000.

KANDEL BA, THOMAS M, WINTER S, DAMM G, SEEHOFER D, BURK O, SCHWAB M, ZANGER UM: Genomewide comparison of the inducible transcriptomes of nuclear receptors CAR, PXR and PPAR $\alpha$ in primary human hepatocytes. Biochim Biophys Acta 1859: 1218-1227, 2016.

KHAN AA, CHOW EC, VAN LOENEN-WEEMAES AM, PORTE RJ, PANG KS, GROOTHUIS GM: Comparison of effects of VDR versus PXR, FXR and GR ligands on the regulation of CYP3A isozymes in rat and human intestine and liver. Eur J Pharm Sci 37: 115-125, 2009.

KHAN AA, DRAGT BS, PORTE RJ, GROOTHUIS GM: Regulation of VDR expression in rat and human intestine and liver - Consequences for CYP3A expression. Toxicol In Vitro 24: 822-829, 2010.

KIR S, KLIEWER SA, MANGELSDORF DJ: Roles of FGF19 in liver metabolism. Cold Spring Harb Symp Quant Biol 76: 139-144, 2011.

KLIEWER SA, MOORE JT, WADE L, STAUDINGER JL, WATSON MA, JONES SA, MCKEE DD, OLIVER BB, WILLSON TM, ZETTERSTRÖM RH, PERLMANN T, LEHMANN JM: An orphan nuclear receptor activated by pregnanes defines a novel steroid signaling pathway. Cell 92: 73-82, 1998.

KRATTINGER R, BOSTROM A, LEE SM, THASLER WE, SCHIOTH HB, KULLAK-UBLICK GA, MWINYI J: Chenodeoxycholic acid significantly impacts the expression of miRNAs and genes involved in lipid, bile acid and drug metabolism in human hepatocytes. Life Sci 156: 47-56, 2016.

KUROSAWA S, UCHIDA S, ITO Y, YAMADA S: Effect of ursodeoxycholic acid on the pharmacokinetics of midazolam and CYP3A in the liver and intestine of rats. Xenobiotica 39: 162-170, 2009.

KWONG E, LI Y, HYLEMON PB, ZHOU H: Bile acids and sphingosine-1-phosphate receptor 2 in hepatic lipid metabolism. Acta Pharm Sin B 5: 151-157, 2015.

LEHMANN JM, KLIEWER SA, MOORE LB, SMITH-OLIVER TA, OLIVER BB, SU JL, SUNDSETH SS, WINEGAR DA, BLANCHARD DE, SPENCER TA, WILLSON TM: Activation of the nuclear receptor LXR by oxysterols defines a new hormone response pathway. J Biol Chem 272: 3137-3140, 1997.

LEHMANN JM, MCKEE DD, WATSON MA, WILLSON TM, MOORE JT, KLIEWER SA: The human orphan nuclear receptor PXR is activated by compounds that regulate CYP3A4 gene expression and cause drug interactions. J Clin Invest 102: 1016-1023, 1998.

LI T, CHANDA D, ZHANG Y, CHOI HS, CHIANG JY: Glucose stimulates cholesterol 7alpha-hydroxylase gene transcription in human hepatocytes. J Lipid Res 51: 832-842, 2010.

LI T, CHIANG JY: Bile acids as metabolic regulators. Curr Opin Gastroenterol 31: 159-165, 2015. 
LI T, FRANCL JM, BOEHME S, OCHOA A, ZHANG Y, KLAASSEN CD, ERICKSON SK, CHIANG JY: Glucose and insulin induction of bile acid synthesis: mechanisms and implication in diabetes and obesity. $J$ Biol Chem 287: 1861-1873, 2012.

MAKISHIMA M, LU TT, XIE W, WHITFIELD GK, DOMOTO H, EVANS RM, HAUSSLER MR, MANGELSDORF DJ: Vitamin D receptor as an intestinal bile acid sensor. Science 296: 1313-1316, 2002.

MAKISHIMA M, OKAMOTO AY, REPA JJ, TU H, LEARNED RM, LUK A, HULL MV, LUSTIG KD, MANGELSDORF DJ, SHAN B: Identification of a nuclear receptor for bile acids. Science 284: 1362-1365, 1999.

MODICA S, GADALETA RM, MOSCHETTA A: Deciphering the nuclear bile acid receptor FXR paradigm. Nucl Recept Signal 8: e005, 2010.

MODICA S, MOSCHETTA A: Nuclear bile acid receptor FXR as pharmacological target: are we there yet? FEBS Lett 580: 5492-5499, 2006.

MOSCHETTA A: Nuclear receptors and cholesterol metabolism in the intestine. Atheroscler Suppl 17: 9-11, 2015.

MUDALIAR S, HENRY RR, SANYAL AJ, MORROW L, MARSCHALL HU, KIPNES M, ADORINI L, SCIACCA CI, CLOPTON P, CASTELLOE E, DILLON P, PRUZANSKI M, SHAPIRO D: Efficacy and safety of the farnesoid $\mathrm{X}$ receptor agonist obeticholic acid in patients with type 2 diabetes and nonalcoholic fatty liver disease. Gastroenterology 145: 574-582, 2013.

NEUSCHWANDER-TETRI BA, LOOMBA R, SANYAL AJ, LAVINE JE, VAN NATTA ML, ABDELMALEK MF, CHALASANI N, DASARATHY S, DIEHL AM, HAMEED B, KOWDLEY KV, MCCULLOUGH A, TERRAULT N, CLARK JM, TONASCIA J, BRUNT EM, KLEINER DE, DOO E, NETWORK NCR: Farnesoid X nuclear receptor ligand obeticholic acid for non-cirrhotic, non-alcoholic steatohepatitis (FLINT): a multicentre, randomised, placebo-controlled trial. Lancet 385: 956-965, 2015.

OTTE K, KRANZ H, KOBER I, THOMPSON P, HOEFER M, HAUBOLD B, REMMEL B, VOSS H, KAISER C, ALBERS M, CHERUVALLATH Z, JACKSON D, CASARI G, KOEGL M, PÄÄBO S, MOUS J, KREMOSER C, DEUSCHLE U: Identification of farnesoid X receptor beta as a novel mammalian nuclear receptor sensing lanosterol. Mol Cell Biol 23: 864-872, 2003.

PARKS DJ, BLANCHARD SG, BLEDSOE RK, CHANDRA G, CONSLER TG, KLIEWER SA, STIMMEL JB, WILLSON TM, ZAVACKI AM, MOORE DD, LEHMANN JM: Bile acids: natural ligands for an orphan nuclear receptor. Science 284: 1365-1368, 1999.

PELLICCIARI R, FIORUCCI S, CAMAIONI E, CLERICI C, COSTANTINO G, MALONEY PR, MORELLI A, PARKS DJ, WILLSON TM: 6alpha-ethyl-chenodeoxycholic acid (6-ECDCA), a potent and selective FXR agonist endowed with anticholestatic activity. J Med Chem 45: 3569-3572, 2002.

PENG L, PIEKOS S, GUO GL, ZHONG X-B: Role of farnesoid X receptor in establishment of ontogeny of phase-I drug metabolizing enzyme genes in mouse liver. Acta Pharm Sin B, 2016.

POUPON R: Ursodeoxycholic acid and bile-acid mimetics as therapeutic agents for cholestatic liver diseases: An overview of their mechanisms of action. Clin Res Hepatol Gastroenterol 36: 3-12, 2012.

POUPON, R: Evidence-based treatment of primary biliary cirrhosis. Dig Dis 32, 626-630, 2014.

QATANANI M, MOORE DD: CAR, the continuously advancing receptor, in drug metabolism and disease. Curr Drug Metab 6: 329-339, 2005.

RAO YP, VLAHCEVIC ZR, STRAVITZ RT, MALLONEE DH, MULLICK J, AVADHANI NG, HYLEMON PB: Down-regulation of the rat hepatic sterol 27-hydroxylase gene by bile acids in transfected primary hepatocytes: possible role of hepatic nuclear factor 1 alpha. J Steroid Biochem Mol Biol 70: 1-14, 1999.

RATZIU V: Treatment of NASH with ursodeoxycholic acid: pro. Clin Res Hepatol Gastroenterol 36 (Suppl. 1): S41-S45, 2012.

RENGA B, MENCARELLI A, CIPRIANI S, D'AMORE C, CARINO A, BRUNO A, FRANCISCI D, ZAMPELLA A, DISTRUTTI E, FIORUCCI S: The bile acid sensor FXR is required for immune-regulatory activities of TLR-9 in intestinal inflammation. PLoS One 8: e54472, 2013.

ROMA M, TOLEDO F, BOAGLIO A, BASIGLIO C, CROCENZI F, POZZI E: Ursodeoxycholic acid in cholestasis: linking action mechanisms to therapeutic applications. Clin Sci 121: 523-544, 2011. 
SATO H, MACCHIARULO A, THOMAS C, GIOIELLO A, UNE M, HOFMANN AF, SALADIN R, SCHOONJANS K, PELLICCIARI R, AUWERX J: Novel potent and selective bile acid derivatives as TGR5 agonists: biological screening, structure-activity relationships, and molecular modeling studies. J Med Chem 51: 1831-1841, 2008.

SATO K, KAMADA T: Regulation of bile acid, cholesterol, and fatty acid synthesis in chicken primary hepatocytes by different concentrations of T0901317, an agonist of liver X receptors. Comp Biochem Physiol A Mol Integr Physiol 158: 201-206, 2011.

SBERNA AL, ASSEM M, GAUTIER T, GROBER J, GUIU B, JEANNIN A, PAIS DE BARROS JP, ATHIAS A, LAGROST L, MASSON D: Constitutive androstane receptor activation stimulates faecal bile acid excretion and reverse cholesterol transport in mice. J Hepatol 55: 154-161, 2011.

SCHUETZ E, STROM S, YASUDA K, LECUREUR V, ASSEM M, BRIMER C, LAMBA J, KIM R, RAMACHANDRAN V, KOMOROSKI B, VENKATARAMANAN R, CAI H, SINAL C, GONZALEZ F, SCHUETZ J: Disrupted bile acid homeostasis reveals an unexpected interaction among nuclear hormone receptors, transporters, and cytochrome p450. J Biol Chem 276: 39411-39418, 2001.

SEPE V, RENGA B, FESTA C, FINAMORE C, MASUllo D, CARINO A, CIPRIANI S, DISTRUTTI E, FIORUCCI S, ZAMPELLA A: Investigation on bile acid receptor regulators. Discovery of cholanoic acid derivatives with dual G-protein coupled bile acid receptor 1 (GPBAR1) antagonistic and farnesoid X receptor (FXR) modulatory activity. Steroids 105: 59-67, 2016.

SILJEVIK ELLIS EC: Suppression of bile acid synthesis by thyroid hormone in primary human hepatocytes. World J Gastroenterol 12: 4640-4645, 2006.

SINGH S, KHANNA S, PARDI D, LOFTUS E, TALWALKAR J: Effect of ursodeoxycholic acid use on the risk of colorectal neoplasia in patients with primary sclerosing cholangitis and inflammatory bowel disease: a systematic review and meta-analysis. Inflamm Bowel Dis 19: 1631-1638, 2013.

SONG C, HIIPAKKA RA, LIAO S: Selective activation of liver X receptor alpha by 6alpha-hydroxy bile acids and analogs. Steroids 65: 423-427, 2000.

SONG C, LIAO S: Cholestenoic acid is a naturally occurring ligand for liver X receptor alpha. Endocrinology 141: 4180-4184, 2000.

SONG KH, CHIANG JY: Glucagon and cAMP inhibit cholesterol 7alpha-hydroxylase (CYP7A1) gene expression in human hepatocytes: discordant regulation of bile acid synthesis and gluconeogenesis. Hepatology 43: 117-125, 2006.

STAUDINGER JL, GOODWIN B, JONES SA, HAWKINS-BROWN D, MACKENZIE KI, LATOUR A, LIU Y, KLAASSEN CD, BROWN KK, REINHARD J, WILLSON TM, KOLLER BH, KLIEWER SA: The nuclear receptor PXR is a lithocholic acid sensor that protects against liver toxicity. Proc Natl Acad Sci U S A 98: 3369-3374, 2001.

STAUFER K, HALILBASIC E, TRAUNER M, KAZEMI-SHIRAZI L: Cystic fibrosis related liver disease-another black box in hepatology. Int J Mol Sci 15: 13529-13549, 2014.

TEBOUL M, ENMARK E, LI Q, WIKSTRÖM AC, PELTO-HUIKKO M, GUSTAFSSON JA: OR-1, a member of the nuclear receptor superfamily that interacts with the 9-cis-retinoic acid receptor. Proc Natl Acad Sci U S A 92: 2096-2100, 1995.

TIMSIT YE, NEGISHI M: CAR and PXR: the xenobiotic-sensing receptors. Steroids 72: 231-246, 2007.

TRAUNER M, CLAUDEL T, FICKERT P, MOUSTAFA T, WAGNER M: Bile acids as regulators of hepatic lipid and glucose metabolism. Dig Dis 28: 220-224, 2010.

TWISK J, HOEKMAN MFM, LEHMANN EM, MEIJER P, MAGER WH, PRINCEN HMG: Insulin suppresses bileacid synthesis in cultured rat hepatocytes by down-regulation of cholesterol 7-alpha-hydroxylase and sterol 27-hydroxylase gene-transcription. Hepatology 21: 501-510, 1995.

UCHIDA S, TANAKA S, NAMIKI N: Simultaneous and comprehensive in vivo analysis of cytochrome P450 activity by using a cocktail approach in rats. Biopharm Drug Dispos 35: 228-236, 2014.

WAGNER M, HALILBASIC E, MARSCHALL HU, ZOLLNER G, FICKERT P, LANGNER C, ZATLOUKAL K, DENK H, TRAUNER M: CAR and PXR agonists stimulate hepatic bile acid and bilirubin detoxification and elimination pathways in mice. Hepatology 42: 420-430, 2005. 
XIANG X, BACKMAN JT, NEUVONEN PJ, NIEMI M: Gender, but not CYP7A1 or SLCO1B1 polymorphism, affects the fasting plasma concentrations of bile acids in human beings. Basic Clin Pharmacol Toxicol 110: 245-252, 2012.

XIANG Z, CHEN Y, MA K, YE Y, ZHENG L, YANG Y, LI Y, JIN X: The role of Ursodeoxycholic acid in nonalcoholic steatohepatitis: a systematic review. BMC Gastroenterol 13, 140, 2013.

XIAO Y, YAN W, ZHOU K, CAO Y, CAI W: Glucocorticoid treatment alters systemic bile acid homeostasis by regulating the biosynthesis and transport of bile salts. Dig Liver Dis 48: 771-779, 2016.

XIE W, BARWICK JL, SIMON CM, PIERCE AM, SAFE S, BLUMBERG B, GUZELIAN PS, EVANS RM: Reciprocal activation of xenobiotic response genes by nuclear receptors SXR/PXR and CAR. Genes Dev 14: 3014-3023, 2000.

XIE W, RADOMINSKA-PANDYA A, SHI Y, SIMON CM, NELSON MC, ONG ES, WAXMAN DJ, EVANS RM: An essential role for nuclear receptors SXR/PXR in detoxification of cholestatic bile acids. Proc Natl Acad Sci US A 98: 3375-3380, 2001.

YAN D, YANG Y, UCHIDA S, MISAKA S, LUO J, TAKEUCHI K, INUI N, YAMADA S, OHASHI K, WATANABE $\mathrm{H}$ : Effects of ursodeoxycholic acid on the pharmacokinetics and pharmacodynamics of intravenous and oral midazolam in healthy volunteers. Naunyn Schmiedebergs Arch Pharmacol 377: 629-636, 2008.

ZELCER N, TONTONOZ P: Liver X receptors as integrators of metabolic and inflammatory signaling. J Clin Invest 116: 607-614, 2006.

ZHANG Y, KAST-WOELBERN HR, EDWARDS PA: Natural structural variants of the nuclear receptor farnesoid $\mathrm{X}$ receptor affect transcriptional activation. J Biol Chem 278: 104-110, 2003.

ZOLLNER G, WAGNER M, MOUSTAFA T, FICKERT P, SILBERT D, GUMHOLD J, FUCHSBICHLER A, HALILBASIC E, DENK H, MARSCHALL HU, TRAUNER M: Coordinated induction of bile acid detoxification and alternative elimination in mice: role of FXR-regulated organic solute transporter-alpha/beta in the adaptive response to bile acids. Am J Physiol Gastrointest Liver Physiol 290: G923-G932, 2006. 